\begin{tabular}{cc|c}
\hline Tar. Bil. Der. & Tarım Bilimleri Dergisi & Journal of Agricultural Sciences \\
& $\begin{array}{c}\text { Dergi web sayfası: } \\
\text { www.agri.ankara.edu.tr/dergi }\end{array}$ & Journal homepage: \\
& www.agri.ankara.edu.tr/journal
\end{tabular}

\title{
Tryptophane and Raw Protein Contents of Local Pea (Pisum sativum L.) Lines for Different Sowing Dates
}

\author{
Reyhan KARAYEL ${ }^{a}$, Hatice BOZOĞLU ${ }^{b}$ \\ ${ }^{a}$ Karadeniz Tarımsal Araştırma Enstitüsü, Tekkeköy, Samsun, TURKEY \\ ${ }^{b}$ Ondokuz Mayıs Üniversitesi, Ziraat Fakültesi, Kurupelit Kampüsü, Tarla Bitkileri Bölümü, 55139, Atakum, Samsun, TURKEY
}

\section{ARTICLE INFO}

Research Article

DOI: 10.1501/Tarimbil 0000001336

Corresponding Author: Reyhan KARAYEL, E-mail: reyhank55@hotmail.com, Tel: +90 (533) 7152220

Received: 28 October 2013, Received in Revised Form: 16 July 2014, Accepted: 11 September 2014

\begin{abstract}
This study was conducted to determine protein and tryptophane contents of own local peas genetic resources and identify whether there is any convenient lines to develop high nutritiousness quality variety. Fortyfour lines used in experimental study, picked before, described morphologically and selected during 6 years as making selection. These lines were sowed on two different sowing times with 4 control varieties under Samsun conditions and dried grain analyzed for their raw protein ratio and tryptophane content. Statistically significant differences were found among sowing times and tested genotypes for the raw protein ratio and tryptophane content. It was determined that both properties were higher in early spring sowing. In winter sowing, raw protein ratio ranged from 17.73 (Bz16) to 28.36\% (Bz42), tryptophane content from 1936.42 (Bz1) to $3119.74 \mathrm{mg} \mathrm{kg}^{-1}$ (Green P.). In spring sowing, raw protein ratio ranged from 19.29 (Bz2) to $27.17 \%$ (Bz 42); tryptophane content from 2231.05 (Bz31) to $2746.44 \mathrm{mg} \mathrm{kg}^{-1}$ (Bz16). Open green grain colored, wrinkle grainy Bz42 line gave the highest value. This line was identified as the most significant candidate line for dry grain purposefully for variety development study.
\end{abstract}

Keywords: Pea; Local; Protein; Tryptophane

\section{Farklı Zamanlarda Ekilen Yerel Bezelye (Pisum sativum L.) Hatlarının Triptofan ve Ham Protein İçerikleri}

\section{ESER BILLGISI}

Araştırma Makalesi

Sorumlu Yazar: Reyhan KARAYEL, E-posta: reyhank55@hotmail.com, Tel: +90 (533) 7152220

Geliş Tarihi: 28 Ekim 2013, Düzeltmelerin Gelişi: 16 Temmuz 2014, Kabul:11 Eylül 2014

\section{ÖZET}

$\mathrm{Bu}$ çalışmanın amacı, elimizdeki yerel bezelye gen kaynaklarının protein ve triptofan amino asiti içeriklerini belirlemek ve besleyicilik kalitesi yüksek çeşit geliştirmeye aday hatların olup olmadığını tespit etmektir. Denemede kullanılan 44 hat daha önce toplanmış, morfolojik tanımlamaları yapılmış ve 6 yıl süre ile seçilmiştir. Bu hatlar iki farklı ekim zamanında 4 kontrol çeşit ile birlikte Samsun şartlarında ekilmiş ve kuru tanelerinde ham protein oranı ve triptofan 
miktarı incelenmiştir. Ham protein oranı ve triptofan miktarı üzerine ekim zamanının istatistiki olarak farklılık yarattığ 1 tespit edilmiştir. Her iki özelliğin de erken ilkbahar ekiminde daha yüksek olduğu görülmüştür. Kışlik ekimde ham protein oran1 \% 17.73 (Bz16) ile \% 28.36 (Bz42), tirptofan miktar1 1936.42 (Bz1) ile $3119.74 \mathrm{mg} \mathrm{kg}^{-1}$ (Green P.) arasında değişmiştir. İlkbahar ekiminde ham protein oranı \% 19.29 (Bz2) ile \% 27.17 (Bz 42), triptofan miktar1 2231.05 (Bz31) ile $2746.44 \mathrm{mg} \mathrm{kg}^{-1}$ (Bz16) arasında değişmiştir. Denemede kullanılan bezelye genotiplerin kuru tohumlarında triptofan miktarı 2167.08-2917.27 mg kg-1 arasında değişmiştir. En yüksek değeri açık yeşil tohum renkli ve kırışık taneli Bz42 hattı vermiştir. Bu hat kuru tane amaçlı çeşit geliştirme çalışması için en önemli aday hat olarak tespit edilmiştir.

Anahtar Kelimeler: Bezelye; Yerel; Protein; Triptofan

(C) Ankara Üniversitesi Ziraat Fakültesi

\section{Indroduction}

Proteins which compose the better part of dry substance weight of a cell and are molecules have a role in whole vital activities (Kandemir \& Kavaklı 2001). Amino acids composed the protein, a human body can not synthesize the eight of them (Leucine, isoleucine, lysine, methionine, phenylalanine, threonine, tryptophane, valine). These amino acids called essential amino acids should be definitely taken on diet sufficiently. The lowest one from dietary amino acids determines protein's biological value (Akçin 1988). Each amino acids have a specific function and could prevent various illness symptoms before develop. Tryptophane balances the body's salt intake. Tryptophane is the basic material on producing painkiller neurotransmitters (serotonin, tryptamine, indoleamin and melatonine) and recognizes damaged unnatural or defective structures of DNA, and fixes them. The factor, which determines ache sense severity, is the tryptophane level that passes brain. However there is a low tryptophane in the brain, one pain such severely. Tryptophane is one of the elements giving color to the eye's iris. It works as a filter against infrared lights and severe lights that can damage the retina. Muscular movements are also significant functions of tryptophane. If there is not any tryptophane in the brain, man can not feel calm and peaceful himself (Batmanghelidj 2012). This amino acid which has so much functions should be taken with diet into the body.

The production of herbal protein isolat has started to become a significant field for industry because of raised concern to herbal proteins at a food and out of food markets. Because of that, in particularly Europe, many countries try to develope their own protein products. The usage of protein isolats as a concentrator adding functional ingredients into food, becomes widespread (Vioque et al 1999). The most widespread usage is soya bean in this way. Including Turkey, Mediterranean basin is the origin central of many protein plants including pea. Pea flour and isolated pea protein are the examples of proteinaceous food. Isolated pea protein is a functional ingredients in terms of putting on water and fat, froth and gelling properties. It is used instead of egg whites for frozen desserts without milk and sponge cakes at the same time. Pea flour which is obtained from grinding pea grains, is a good resource because of that approximately $30 \%$ of total combination is protein (Periago et al 1998).

There is only one registered pea variety on the purpose of using as dry grain but this variety is not used at the present time. Untill today, 1 local 10 exterior registered varieties have been used on market on the purpose of fresh consumption. However, according to Akçin (1988) from Trabut (1911) and Vavilov (1950) have reported Near East and Mediterranean involved our country are also the gene centres of pea as being for many plants. It shows Turkey is lucky on the subject of developing pea varieties from local materials. As well as developable varieties are direct food, considering properties of protein concentrator addictive matter being fund food processing sector and developing.

Pea is enjoyably consumed food both in EU countries and our north and east neighbours, especially China. If Turkey have good varieties and 
cultivating techniques for this product, it is possible to be exporter. Also pea is a addictive product for being founded of food processing industry. Our region has a potential that it has convenient ecology for pea cultivating and its industry can be founded and developed. Because of that, this study was conducted to determine whether there are any candidate varieties which have high protein and amino acid that is suitable for our regional conditions, and after that to breed new cultivar.

\section{Material and Methods}

Materials of this consists of 48 genotype as 44 line which are obtained from National Plant Gene Bank and picked from coastal city of Samsun, brought the line level with selection breeding and as the control, 4 varieties (Klein, Green Pearly, Sprinter, Sugar Bon) selected.

The study was carried out in Samsun located in Coastal Middle Black Sea Region in 2009-2010 cultivating season. Winter sowings were done in november while spring sowings in February. Some soil properties of winter sown experimental area were as follows loamy texture, notral $\mathrm{pH}$ (6.85), slightly saline, high organic matter while that of spring sown experimental area were as follows loamy texture, notral $\mathrm{pH}$ (6.89), non saline and adequate organic matter. Totally $541.2 \mathrm{~mm}$ rain dropped during vegetation in winter sowing period and $506.8 \mathrm{~mm}$ in spring sowing vegetation period.

Experiments was designed as randomized block design with three replications. Genotypes were sowed $50 \times 15 \mathrm{~cm}$ density (each plots 5 square meters) on November 13 (winter) and February 25 (spring). Experiment was carried out in rainfed conditions without irrigation and fertilizer application. Sample was taken from blended and harvested seeds for protein and aminoacid analyses.

\subsection{Raw protein ratio in seed}

Protein content was determined by the Kjeldhal method using Gerhard brand instrument. Nitrogen content in the sample was converted to total protein content by multiplying the $\mathrm{N}$ percentage with the standard conversion factor (6.25).

\subsection{Tryptophane aminoacid quantity in seed}

Tryptophane aminoacid quantity in seed was determined by alkaline hydrolysate method of Fountoulakis \& Lahm (1998) whom reported it has been the most convenient method. Tryptophane stock solution (1000 $\left.\mathrm{mg} \mathrm{L}^{-1}\right)$ was prepared for tryptophane standard by dissolving $0.1 \mathrm{~g}$ of tryptophane in $100 \mathrm{~mL}$ of $0.1 \mathrm{~mol} \mathrm{~L}^{-1} \mathrm{HCl}$ solution. Internal standard prepared by dissolving $0.1 \mathrm{~g}$ of $\alpha$-methyl-tryptophane in $100 \mathrm{~mL}$ of $0.1 \mathrm{~mol} \mathrm{~L}^{-1} \mathrm{HC} 1$ solution. Seven different standard solution were prepared from stock tryptophane solution $(0.001$, $0.025,0.05,0.1,0.25,0.5$ and $1 \mathrm{~mL}$ ). Prepared standards being read on HPLC Thermo SP, TSP, SCM 1000. It was determined tryptophane's coming duration was at 17. min (Figure 1).

In HPLC readings, ultraviolet detector, Luna C18 $(250 \times 4.6 \mathrm{~mm}$, size of shred $5 \mu \mathrm{m}$ colon was used. Colon oven temperature was adapted to 30 ${ }^{\circ} \mathrm{C}$. The solution, that prepared with $3 \mathrm{~g}$ acetic acid, $900 \mathrm{~mL}$ ultra pure water, $50 \mathrm{~mL}$ methanol, $0.5 \mathrm{~g}$ 1,1,1-trichhloro-2-methly-2-propanol, adjusted to pH 5 with ethanolamine solution and volüme made up to $1 \mathrm{~L}$ with ultra pure water, was used as mobile phase. Flow rate $1 \mathrm{~mL} \mathrm{~min}^{-1}$, detector's wave lenght $280 \mathrm{~nm}$, injection volume $20 \mu \mathrm{L}$ and analyse duration as $21 \mathrm{~min}$ were adapted (CD 2000).

Seeds were sifted from $0.5 \mathrm{~mm}$ sieve as graining to determine tryptophane quantity in pea lines. $0.3000 \mathrm{~g}$ (containing $10 \mathrm{mg}$ of nitrojen) from sifted example was weighed in capped autoclavable glass containers. $8.4 \mathrm{~g} \mathrm{Ba}(\mathrm{OH})_{2} 8 \mathrm{H}_{2} \mathrm{O}$ and $10 \mathrm{~mL}$ ultra pure water was added onto it. It was mixed in the magnetic stirrer and $4 \mathrm{~mL}$ ultra pure water was added, and autoclaved during 8 hours in $140{ }^{\circ} \mathrm{C}$ being closed its tubulure (Delhaye \& Landry 1993). After being taken from autoclave it was shaked slightly adding $30 \mathrm{~mL}$ ultra pure water. In pursuit of it, $0.5 \mathrm{~mL}$ severe internal standard solution ( $\alpha$-methyl-tryptophane) was added. After that $5 \mathrm{~mL}$ of $0.5 \mathrm{~mol} \mathrm{~L}^{-1}$ ortho-phosphoric acid solution was added. Solution was adapted to $\mathrm{pH} 3$ with $1 \mathrm{~mol}$ 
$\mathrm{L}^{-1} \mathrm{HCl}$ solution neutrolizing with $6 \mathrm{~mol} \mathrm{~L}^{-1} \mathrm{HC} 1$ solution. To this, after adding $25 \mathrm{~mL}$ methanol, its volume was completed to $100 \mathrm{~mL}$ with ultra pure water was transferred to $100 \mathrm{~mL}$ volumetric flask. Solution was read on HPLC filtered to vial from $0.45 \mu \mathrm{m}$ filter and tryptophane quantity in seed was determined as $\mathrm{mg} \mathrm{kg}^{-1}$.

Statistical analyses were performed compounding over sowing times with respect to randomized complete block design in SPSS13 software. DUNCAN test $(\mathrm{P}<0.01)$ was used for multi comparisons.

\section{Results and Discussion}

\subsection{Raw protein ratio in seed}

One of most important property distinguishes legumes family from other plants made agriculture is being high protein ratio in dry seeds. Singh et al (2003) have reported the protein ratio in pea have the feature of high heredity, indicative low genetic progress and this property can be used as selection criterion. Though the height of heredity degre, environmental factors affect protein ratio. One of these factor is sowing time. Vegetation period is generally longer in winter sowing. Correspondingly, however its ratio in seed have seemed low for more dry matter processing and occured accumulation in seed because of the high yield when calculated protein yield was found high. Accumulation of carbohhydrate in seed has decreased by means of short vegetation period in early spring sowing; depending on it, protein in seed has increased proportionately, in other words quality has stood out. Biçer (1997) has reported that protein ratio in seed has changed between $23.13 \%$ and 31.31 in peas sowed at two different times as november 29 and february 16 under Diyarbakır conditions and the highest ratio was obtained from sowing on february 16. In our study as well, whereas raw protein ratio in seed in genotypes sowed in winter was averagely $20.99 \%$, it was $22.09 \%$ for the ones sowed in early spring. This raise was found significant statistically (Table 1).
In the conclusion of performed variance analyse it was determined that raw protein ratio in seed of peas sowed in winter and early spring, affected significantly $(\mathrm{P}<0.01)$ from sowing dates (Table 1$)$. Raw protein ratio in winter sowed genotypes changed between $17.73 \%$ and $28.36 \%$. 19 genotypes were located over winter sowing experiment avarage. Among varieties, wrinkle grainy Sugar Bon has had the lowest raw protein ratio $(22.17 \%)$ both in winter and early spring sowing and wrinkle grainy Green Pearly has had the highest ratio has given the highest value $(27.17 \%)$ both at two sowing times (Table 1$)$.

Karayel (2006) has reported the raw protein ratio is $20.4 \%$ for Sugar Bon, $19.5 \%$ for Sprinter, $19.2 \%$ for Green Pearly wintery sowed in Samsun; Bozoğlu et al (2004) have reported it has been $30.50 \%$ for Sprinter under the same conditions. Though the same ecology, being high of this difference for varieties has revealed however this property's heredity has been high, it has been affected from cultivating conditions in terms of raw protein ratio. Seed colour for pea has been one of significant quality properties determining whether it has been for cooking or not (Karayel 2012). Particularly in Turkey, light coloured seed types for legumes were preferred as for cooking. In this study, it was determined that 9 from in winter sowing lines had light colour seed, are convenient for cooking; and the others had dark colored seed were convenient for feed. Protein ratio changed between $21.82 \%$ and $27.17 \%$ in control varieties used in the experiment and Green Pearly had the highest ratio. Bz42 line which had the highest raw protein ratio, was wrinkle and light green coloured seed, passed the control varieties (Table 1).

Raw protein ratios of lines changed between $19.29 \%$ and $27.17 \%$ in early spring sowing. Bz42 line had the highest raw protein ratio and also this line passed control varieties. This value changed between $21.52 \%$ and $25.72 \%$ for varieties. As is seen, lines in comporison to varieties had a wide change in terms of protein ratio. Green Pearly had the highest protein ratio in early spring sowing as in winter sowing. The average of early spring sowing was $22.09 \%, 19$ genotypes were passed the average 


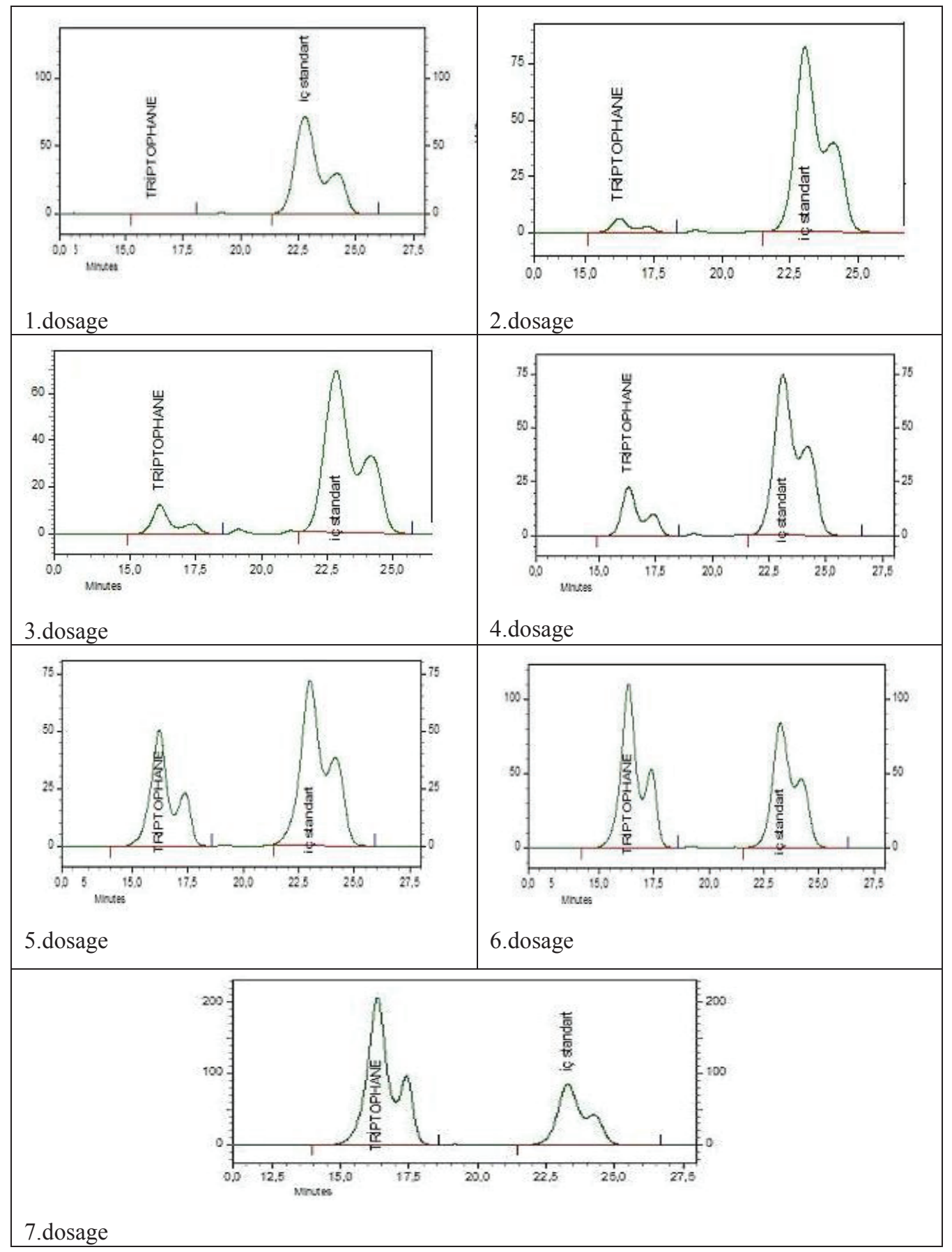

Figure 1- Chromatograms of tryptophane amino acid standarts

Şekil 1- Triptofan amino asiti standartlarının kromatogramları 
Table 1- Raw protein ratios and tryptophane quantity of pea genotypes sowed in winter and early spring Çizelge 1- Klşlık ve erken ilkbaharda ekilen bezelye genotiplerinin tanede ham protein oranları ve triptofan miktarlart

\begin{tabular}{|c|c|c|c|c|c|c|}
\hline \multirow[b]{2}{*}{ Genotypes } & \multicolumn{3}{|c|}{ Raw protein ratio in seed (\%) } & \multicolumn{3}{|c|}{ Tryptophane quantity in seed ( $\left.m g \mathrm{~kg}^{-1}\right)$} \\
\hline & Winter & Spring & Mean $^{* *}$ & Winter & Spring & Mean $^{* *}$ \\
\hline Bz1 & 19.19 & 22.65 & $20.92 \mathrm{j}-\mathrm{t}$ & 1936.42 & 2397.74 & $2167.08 \mathrm{t}$ \\
\hline Bz2 & 22.01 & 19.29 & $20.65 \mathrm{k}-\mathrm{t}$ & 2546.35 & 2350.89 & 2448.62 e-m \\
\hline $\mathrm{Bz} 3$ & 19.56 & 22.02 & $20.79 \mathrm{j}-\mathrm{t}$ & 2186.61 & 2438.39 & $2312.501-\mathrm{t}$ \\
\hline $\mathrm{Bz} 4$ & 19.40 & 22.50 & $20.95 \mathrm{i}-\mathrm{t}$ & 2095.75 & 2491.00 & $2293.37 \mathrm{~m}-\mathrm{t}$ \\
\hline $\mathrm{Bz} 5$ & 21.03 & 19.57 & $20.30 \mathrm{r}-\mathrm{u}$ & 2486.89 & 2321.01 & $2403.95 \mathrm{f}-\mathrm{o}$ \\
\hline Bz6 & 20.97 & 19.85 & $20.41 \mathrm{o}-\mathrm{u}$ & 2282.81 & 2349.63 & $2316.22 \mathrm{k}-\mathrm{t}$ \\
\hline $\mathrm{Bz} 7$ & 21.12 & 19.35 & $20.24 \mathrm{stu}$ & 2499.59 & 2401.76 & 2450.68 e-m \\
\hline $\mathrm{Bz} 8$ & 19.69 & 21.78 & $20.74 \mathrm{j}-\mathrm{t}$ & 2404.62 & 2583.82 & $2494.22 \mathrm{~d}-\mathrm{j}$ \\
\hline $\mathrm{Bz} 9$ & 18.97 & 19.74 & $19.35 \mathrm{u}$ & 2057.44 & 2346.51 & $2201.98 \mathrm{rst}$ \\
\hline Bz10 & 20.91 & 20.84 & $20.48 n-u$ & 2538.52 & 2406.41 & $2472.46 \mathrm{~d}-1$ \\
\hline Bz11 & 21.25 & 20.18 & $20.71 \mathrm{j}-\mathrm{t}$ & 2490.65 & 2307.52 & 2399.08 f-o \\
\hline Bz12 & 21.18 & 22.75 & $21.96 \mathrm{e}-\mathrm{j}$ & 2584.98 & 2485.95 & $2535.46 \mathrm{c}-\mathrm{g}$ \\
\hline Bz13 & 18.60 & 21.62 & $20.11 \mathrm{stu}$ & 2096.88 & 2539.39 & $2318.13 \mathrm{j}-\mathrm{t}$ \\
\hline Bz14 & 22.46 & 19.83 & $21.14 \mathrm{~h}-\mathrm{s}$ & 2473.67 & 2336.27 & $2404.97 \mathrm{f}-\mathrm{o}$ \\
\hline Bz15 & 21.79 & 22.95 & $22.37 \mathrm{~d}-\mathrm{h}$ & 2643.14 & 2303.56 & $2473.35 \mathrm{~d}-1$ \\
\hline Bz16 & 17.73 & 25.46 & $21.60 \mathrm{f}-\mathrm{p}$ & 2102.57 & 2746.44 & 2424.50 e-m \\
\hline Bz17 & 21.49 & 23.99 & 22.74 def & 2563.79 & 2664.50 & $2614.14 \mathrm{bcd}$ \\
\hline Bz18 & 19.80 & 26.57 & $23.18 \mathrm{~d}$ & 2184.15 & 2718.06 & $2451.11 \mathrm{e}-\mathrm{m}$ \\
\hline Bz19 & 19.54 & 21.66 & $20.60 \mathrm{k}-\mathrm{t}$ & 2158.57 & 2508.81 & $2333.69 \mathrm{j}-\mathrm{t}$ \\
\hline Bz20 & 21.04 & 22.42 & $21.73 \mathrm{f}-\mathrm{n}$ & 2338.34 & 2509.93 & $2424.13 \mathrm{e}-\mathrm{m}$ \\
\hline $\mathrm{Bz} 21$ & 20.53 & 22.24 & $21.39 \mathrm{~g}-\mathrm{s}$ & 2358.82 & 2644.43 & $2501.63 \mathrm{~d}-\mathrm{i}$ \\
\hline $\mathrm{Bz} 22$ & 20.59 & 22.72 & $21.66 \mathrm{f}-\mathrm{o}$ & 2345.04 & 2453.03 & $2399.04 \mathrm{f}-\mathrm{o}$ \\
\hline $\mathrm{Bz} 23$ & 21.63 & 21.67 & $21.65 \mathrm{f}-\mathrm{o}$ & 2526.70 & 2588.10 & $2557.40 \mathrm{c}-\mathrm{f}$ \\
\hline $\mathrm{Bz} 24$ & 18.34 & 21.16 & $19.75 \mathrm{tu}$ & 2221.29 & 2394.92 & $2308.101-\mathrm{t}$ \\
\hline $\mathrm{Bz} 25$ & 19.94 & 21.18 & $20.56 \mathrm{~m}-\mathrm{u}$ & 2308.47 & 2392.94 & $2350.71 \mathrm{i}-\mathrm{r}$ \\
\hline Bz26 & 22.19 & 22.20 & $22.19 \mathrm{~d}-\mathrm{i}$ & 2705.96 & 2431.73 & 2568.85 b-e \\
\hline $\mathrm{Bz} 27$ & 20.27 & 20.46 & 20.37 p-u & 2332.04 & 2477.05 & $2404.55 \mathrm{f}-\mathrm{o}$ \\
\hline $\mathrm{Bz} 28$ & 21.81 & 21.50 & $21.66 \mathrm{f}-\mathrm{o}$ & 2489.83 & 2348.79 & 2419.31 e-n \\
\hline Bz29 & 18.99 & 21.22 & $20.11 \mathrm{stu}$ & 1994.46 & 2381.24 & $2187.85 \mathrm{st}$ \\
\hline $\mathrm{Bz} 30$ & 19.19 & 22.32 & $20.75 \mathrm{j}-\mathrm{t}$ & 2198.41 & 2401.89 & $2300.15 \mathrm{~m}-\mathrm{t}$ \\
\hline Bz31 & 19.17 & 20.25 & $19.71 \mathrm{tu}$ & 2189.68 & 2231.05 & 2210.37 p-t \\
\hline Bz32 & 20.19 & 22.87 & $21.53 \mathrm{f}-\mathrm{r}$ & 2293.48 & 2446.56 & $2370.02 \mathrm{~h}-\mathrm{p}$ \\
\hline Bz33 & 22.69 & 23.41 & 23.05 de & 2498.28 & 2551.80 & $2525.04 \mathrm{c}-\mathrm{h}$ \\
\hline Bz34 & 22.06 & 20.58 & 21.32 g-s & 2507.85 & 2280.58 & $2394.21 \mathrm{f}-\mathrm{o}$ \\
\hline Bz35 & 20.33 & 21.29 & $20.81 \mathrm{j}-\mathrm{t}$ & 2421.59 & 2536.76 & $2479.17 \mathrm{~d}-\mathrm{k}$ \\
\hline Bz36 & 21.62 & 21.84 & $21.73 \mathrm{f}-\mathrm{n}$ & 2132.26 & 2385.27 & $2258.76 \mathrm{n}-\mathrm{t}$ \\
\hline Bz37 & 21.91 & 20.46 & $21.19 \mathrm{~h}-\mathrm{s}$ & 2390.19 & 2294.11 & $2342.15 \mathrm{i}-\mathrm{s}$ \\
\hline Bz38 & 18.31 & 22.83 & $20.571-u$ & 2144.69 & 2593.89 & 2369.29 h-p \\
\hline Bz39 & 21.24 & 19.48 & 20.36 p-u & 2502.59 & 2359.76 & $2431.18 \mathrm{e}-\mathrm{m}$ \\
\hline $\mathrm{Bz} 40$ & 20.47 & 20.78 & $20.63 \mathrm{k}-\mathrm{t}$ & 2412.69 & 2383.62 & $2398.15 \mathrm{f}-\mathrm{o}$ \\
\hline Bz41 & 20.12 & 24.95 & $22.54 \mathrm{~d}-\mathrm{g}$ & 2156.34 & 2585.87 & 2371.10 g-p \\
\hline $\mathrm{Bz} 42$ & 28.36 & 27.17 & $27.77 \mathrm{a}$ & 2711.88 & 2710.45 & $2711.16 \mathrm{~b}$ \\
\hline $\mathrm{Bz} 43$ & 25.46 & 24.51 & $24.98 \mathrm{c}$ & 2674.26 & 2657.67 & $2665.97 \mathrm{bc}$ \\
\hline $\mathrm{Bz} 44$ & 18.94 & 24.77 & $21.85 \mathrm{f}-1$ & 2172.61 & 2518.30 & 2345.46 i-s \\
\hline Klein & 21.82 & 21.92 & $21.87 \mathrm{f}-\mathrm{k}$ & 2074.25 & 2416.93 & $2245.59 \mathrm{o}-\mathrm{t}$ \\
\hline Sugar B. & 22.17 & 21.52 & $21.84 \mathrm{f}-\mathrm{m}$ & 2374.20 & 2596.52 & $2485.36 \mathrm{~d}-\mathrm{j}$ \\
\hline Sprinter & 24.31 & 25.16 & $24.73 \mathrm{c}$ & 2545.95 & 2716.51 & $2631.23 \mathrm{bcd}$ \\
\hline Green P. & 27.17 & 25.72 & $26.44 \mathrm{~b}$ & 3119.74 & 2714.81 & $2917.27 \mathrm{a}$ \\
\hline Mean $^{* *}$ & $20.99 \mathrm{~B}$ & $22.09 \mathrm{~A}$ & & $2364.07 \mathrm{~B}$ & $2472.96 \mathrm{~A}$ & \\
\hline
\end{tabular}


and 10 of them had dark color seed. Lines had the lowest protein ratio both in two sowing, had small, dark green colored seed, black hilum, short pod were feed type, were not convenient for cooking. These lines are suggested as feed considering rich protein content. Timuroğlu et al (2004) have determined raw protein ratio of some pea lines which were sowed as summery and developed as feeder under Ankara conditions changed between 16 and 23.5\%. Seyis (1994) has determined raw protein ratio of summer sowed pea varieties in Samsun changed between 18.72 and $24.37 \%$ and also Gülümser et al (1994) have determined it changed between 19.75 and $24.01 \%$ at the same ecology.

In the conclusion of variance analyse performed for the raw protein ratio in seed of 48 genotype (for line and control) sowed in winter and early spring, the difference $(\mathrm{P}<0.01)$ was seen between genotypes and in terms of sowing time $\mathrm{x}$ genotype interaction. When lines were evaluted without sowing times, raw protein ratio in seed changed between $19.35 \%$ and $27.77 \%$ and for varieties $21.84 \%-26.44 \%$ and it is monitored local materials passed control varieties. Bz9 lines had the lowest raw protein ratio in seed, had the feature of brownish green, dimpled whereas the highest line is Bz42 which had the highest raw protein ratio, had the feature of light green, wrinkle seed both in winter and early spring sowing. This type looked appropriate for cooking pea cultivation.

\subsection{Tryptophane aminoacid quantity in seed}

In the conclusion of variance analyses it was determined there was statistically a difference $(\mathrm{P}<0.01)$ between winter and early spring sowing in terms of tryptophane quantity of pea genotypes. Tryptophane quantity in seed was found more high in early spring sowing than in winter sowing (Table 1). Being high of protein ratio in early spring sowing as well resulted in that conclusion.

Showing chromatograms tryptophane values of some genotypes in winter sowing were given at Figure 2. Tryptophane quantity of Bz26, Bz44



Figure 2- Tryptophane chromatograms of some genotypes in winter sowing

Şekil 2- Bazı genotiplerin kışlık ekimdeki triptofan kromatogramları 
and Green Pearly, which cromotography can be see in Figure 2, were determined 2705.96, 2172.61 and $3119.74 \mathrm{mg} \mathrm{kg}^{-1}$, respectively. Tryptophane quantity of lines in winter sowing changed between 1936.42 and $2711.88 \mathrm{mg} \mathrm{kg}^{-1}\left(1.009-0.956{\mathrm{~g} 16 \mathrm{~g}^{-1}}^{-1}\right.$ $\mathrm{N})$, whereas 2074.25-3119.74 $\mathrm{mg} \mathrm{kg}^{-1}(0.951-1.148$ g $\left.16 \mathrm{~g}^{-1} \mathrm{~N}\right)$ for conrol varieties. In early spring sowing tryptophane quantity of lines changed between 2231.05 and $2746.44 \mathrm{mg} \mathrm{kg}^{-1}$ (1.102-

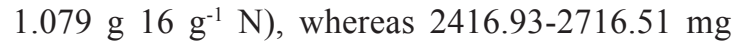

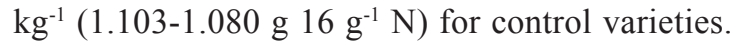
The highest quantity of tryptophane $(3119.74 \mathrm{mg}$

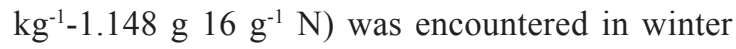
sowing Green Pearly. Some genotypes' tryptophane quantity belonging to HPLC chromatograms were given at Figure 2. Chavan et al (1999) determined tryptophane quantitative in Pisum sativum as

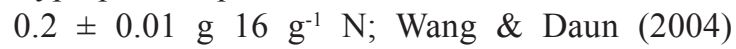
determined tryptophane quantitative in Canada pea

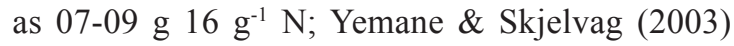

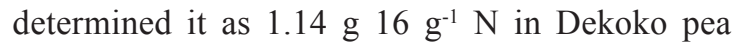

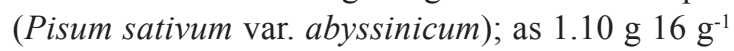
$\mathrm{N}$ in Ater (Pisum sativum var. sativum). Khattab et al (2009) determined there was 0.61-0.86 g tryptophane in $100 \mathrm{~g}$ protein of uncured dry pea in their study researching feed quality of legume seeds some physical applicants done. Iqbal et al (2006) investigated the feed quality of significant edible legumes (chickpea, lentil, cowpea, green pea). They have determined tryptophane quantitative in green pea's protein as $0.8 \pm 0.02 \%$.

In the conclusion of variance analyses performed for tryptophane quantity in seed of 48 genotypes sowed in winter and early spring, there was a different $\mathrm{P}<0.01$ level between genotypes and sowing times $\mathrm{x}$ genotype interaction. The highest tryptophane quantity was in Bz42 line that was light green and wrinkle, its tryptophane

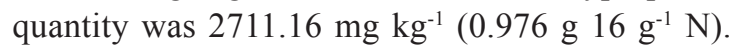
Bz17, Bz26, Bz43 lines and also Sprinter control variety were placed in the same statistical group. Bz42 line except Green Pearly (2917.27 ppm) had higher tryptophane quantity than other control varieties.

\section{Conclusions}

The raw protein ratio, one of the most important properties of legumes changed 19.35-27.77\% for genotypes and it is monitored local materials passed control varieties. Bz42 line is the most remarkable material due to higher protein ratio $(27.77 \%)$ than Green Pearly control variety, which the highest protein ratio (26.44\%) has become. Besides, tryptophane quantitative of lines have changed 2167.08-2711.16 mg kg-1. Having the highest tryptophane quantitative of Bz42 has had the feature of light green colored, wrinkle seed, can be suggested to develop variety convenient on the purpose of dry grain.

\section{References}

Akçin A (1988). Yemeklik Dane Baklagiller. Selçuk Üniversitesi Yayınları: 43, Ziraat Fakültesi Yayınları: 8, Konya

Batmanghelidj F (2012). Su: Hasta Değil Susuzsunuz. Klan Yayınları, İstanbul

Biçer B T (1997). Diyarbakır koşullarında tane bezelye çeşitlerinde sulama ve ekim zamanının verim ve verim unsurlarına etkisi üzerine bir araştırma. Yüksek lisans tezi, Dicle Üniversitesi Fen Bilimleri Enstitüsü (Basılmamış), Diyarbakır

Bozoğlu H, Pekşen E \& Gülümser A (2004). Sıra aralığı ve potasyum humat uygulamasinın bezelyenin verim ve bazı özelliklerine etkisi. Tarım Bilimleri Dergisi Journal of Agricultural Sciences 10(1): 53-58

Chavan U D, Shahidi F, Bal A K \& McKenzie D B (1999). Physico-chemical properties and nutrient composition of beach pea (Lathyrus maritimus L.). Food Chemistry 66: $43-50$

Commission Directive (CD) (2000). Determination of tryptophan. Commission Directive, Official Journal of the European Communities 45/EC. L 174: 45-50

Delhaye S \& Landry J (1993). Quantitative determination of tryptophan in food and feedstuffs: practical considerations on autoclaving samples for hydrolysis. Journal Agricultural Food Chemistry 41: 1633-1634

Fountoulakis M \& Lahm H (1998). Hydrolysis and aminoacid composition analysis of proteins. Journal of Chromatography A 826: 109-134

Gülümser A, Seyis F \& Bozoğlu H (1994). Samsun ekolojik şartlarında kışlık ve yazlık olarak ekilen 
bezelye çeşitlerinin konservecilik özellikleri ile tane veriminin tespiti. E.Ü.Z.F. Tarla Bitkileri Bölümü Tarla Bitkileri Bilim Derneği TUBITTAK ve ÜSIGGEM. Tarla Bitkileri Kongresi, Cilt I Agronomi Bildirileri, 25-29 Nisan, İzmir, Türkiye, s. 87-90

Iqbal A, Khalil I A, Ateeq N \& Khan M S (2006). Nutritional quality of important food legumes. Food Chemistry 97: 331-335

Kandemir N \& Kavaklı İ H (2001). Proteinler ve protein mühendisliği. (Editörler: S Özcan, E Gürel \& M Babaoğlu), Bitki Biyoteknolojisi Cilt:2, Selçuk Üniversitesi Vakfı Yayınları, Konya, s. 364-400

Karayel R (2006). Yerel bezelye genotiplerinin tanımlanması ve bazı agronomik özelliklerinin tespiti. Yüksek lisans tezi, Ondokuz Mayıs Üniversitesi Fen Bilimleri Enstitüsü (Basılmamış), Samsun

Karayel R (2012). Samsun'da ekilen bezelye genotiplerinin bazı fizikokimyasal özelliklerinin belirlenmesi ve 1slah materyali olarak uygunluğunun değerlendirilmesi. Doktora tezi, Ondokuz Mayıs Üniversitesi Fen Bilimleri Enstitüsü (Basılmamış), Samsun

Khattab R Y, Arntfield S D \& Nyachoti C M (2009). Nutritional quality of legume seed as affected by some physical treatments, Part 1: Protein quality evaluation. LWT-Food Science and Technology 42: 1107-1112

Periago M J, Vidal M L, Ros G, Rincon F, Martinez C, Lopez G, Rodrigo J \& Martinez I (1998). Influence of enzymatic treatment on the nutritional and functional properties of pea flour. Food Chemistry 63(1): 71-78

Seyis F (1994). Samsun ekolojik şartlarında yazlık olarak ekilen bezelye çeşitlerinin tane verimi ile bazı önemli özellikleri ve bunlar arasındaki ilişkiler üzerine bir araştırma. Yüksek lisans tezi, Ondokuz Mayıs Üniversitesi Fen Bilimleri Enstitüsü (Basılmamış), Samsun

Singh G, Singh M, Singh V \& Singh B (2003). Genetic variability, heritability and genetic advance in pea (Pisum sativum L.). Progressive Agriculture 3(1-2): 70-73

Timuroğlu K A, Genç A \& Altınok S (2004). Ankara koşullarında yem bezelyesi hatlarında yem ve tane verimleri. Tarım Bilimleri Dergisi 10(4): 457-461

Vioque R S, Clemente A, Vioque J, Bautista J \& Millan F (1999). Protein isolates from chickpea (Cicer arietinum L.): chemical composition, functional properties and protein characterization. Food Chemistry 64: 237-243

Wang N \& Daun J K (2004). The chemical composition and nutritive value of canadian pulses, field pea (Pisum sativum). Canadian Grain Commission

Yemane A \& Skjelvag A O (2003). Physicochemical traits of Dekoko (Pisum sativum var. abyssinicum) seeds. Plant Foods for Humman Nutrition 58: 275-283 